\title{
The Objectives and Practical Aspects of Quality Assurance System of Higher Education
}

\author{
Dora H. Ivanova ${ }^{1}$, Olga V. Goray ${ }^{2}$, Nadiia I. Horbachova ${ }^{3}$, Iryna M. Krukovska ${ }^{2} \&$ Svitlana D. Poplavska $^{3}$ \\ ${ }^{1}$ Department of General Pedagogics, Preschool, Primary and Special Education, Pedagogical Faculty, Izmail State \\ University of Humanities, Izmail, Ukraine \\ ${ }^{2}$ Department of Natural and Social and Humanitarian Disciplines, MHEI "Zhytomyr Medical Institute" Zhytomyr \\ Regional Council, Zhytomyr, Ukraine \\ ${ }^{3}$ Department of English Philology and Translation, Educational and Research Institute of Foreign Philology, \\ Zhytomyr Ivan Franko State University, Zhytomyr, Ukraine \\ Correspondence: Dora H. Ivanova, Izmail State University of Humanities, 12 Repina str., Izmail, 68601, Ukraine.
}

Received: June 10, 2020

Accepted: August 3, 2020

Online Published: August 4, 2020

doi:10.5430/ijhe.v9n7p119

URL: https://doi.org/10.5430/ijhe.v9n7p119

\begin{abstract}
Each country in the world has its own individual approaches to the quality assurance system of higher education, so the quality of educational services in each country is different. The developing countries should be guided by the standards and recommendations put forward by the world's leading countries in the field of the assurance system of higher education in order to improve the quality of education services. The purpose of the scientific investigation is to formulate the objectives and analyze the practical aspects of functioning of the quality assurance system of higher education. In the study's framework of the practical aspects of the higher education's quality in European Union's countries, the methods of general analysis have been used, including comparison and grouping; at the same time, the presentation of statistics is also demonstrated by graphical methods. The practical aspects of quality assurance of higher education in European Union's countries have been analyzed, which is reflected in the dynamics of the number of students who have received higher education, the structure of higher education degree seeking applicants, the employment rate of graduates who have graduated from higher education institutions (Employment rates of recent graduates), the World University Rankings, the Europe Teaching Rankings, rating of the strength of the higher education system (the QS Higher Education System Strength Rankings). Proposals for ensuring the proper quality of higher education and a high level of educational services to educational institutions of the European Union have been presented.
\end{abstract}

Keywords: quality of higher education, educational services, standards, strength of higher education system

\section{Introduction}

One of the crucial tasks of successful functioning of almost every country (whether economically developed or developing) is to ensure the quality of higher education in the conditions of rapid development of market environment and adverse effects of globalization processes. It should be noted that the quality of educational services in each country is different, which, as a consequence, affects the results of satisfaction with these services.

Therefore, in the context of ensuring the proper quality of higher education in each country, it is advisable, first of all, to consider the existing standards for the provision of educational services by the leading countries of the world. This, in turn, will help to improve the level of educational services not only in developing countries but also in highly developed countries by examining individual experience and practical aspects of providing educational services.

The quality assurance system of higher education is being transformed by ensuring the adaptability and flexibility of higher education. The concept of interactive pedagogy is being developed due to digital technologies (Stewart \& Wolodko, 2016). Flexibility of higher education involves adaptation to the needs of students (Arrosagaray, González-Peiteado, Pino-Juste \& Rodríguez-López, 2019), availability of educational materials at anytime, anywhere (Adams et al., 2017). Higher education is being intensified through innovative education technologies and improved communication between teachers and students (Keane, Keane \& Blicblau, 2016). As a result, synergy is ensured: pedagogical, professional, social, catalytic and technical effects are integrated (Jain \& Tyagi, 2017). 
Taking this into consideration, the purpose of the academic paper is to form tasks and analyze the practice of the quality assurance system of higher education. The following tasks should be considered and solved in order to achieve the purpose of the academic paper, namely:

1) To investigate the theoretical, methodical and methodological principles of the quality assurance system of higher education;

2) To consider and analyze the features of the formation and development of the quality assurance system of higher education in the member states of the European Union;

3) To provide recommendations to educational institutions of European Union member states on ensuring the proper quality of higher education and a high level of educational services.

\section{Literature Review}

Studies prove that the topic of quality assurance of higher education is presented in the works of many leading scientists and scholars.

In view of the findings of a survey conducted in German higher education institutions by Seyfried and Pohlenz (2018), it has been found that the achievement of a high level of quality assurance in higher education would, to a large extent, be supported by higher education management, as well as the approval of cooperation with other educational institutions. Moreover, these authors also emphasize that "quality managers' role as promoters of quality assurance exhibits significant correlations with perceived effectiveness" (Seyfried \& Pohlenz, 2018).

At the same time, Filippakou (2011) presents a conceptual approach to the idea of quality in higher education. The scientist has proven that the concept of quality in higher education has been ideologically created, and the regime of this quality provides a fairly narrow range of understanding of higher education. In the context of the above, the researcher suggests using discourse and power to emphasize the interconnection of ideology and quality in higher education.

Elken and Stensaker (2018) have highlighted three areas for improving the provision of higher education as part of quality upgrading of this process. Therefore, the improvements are related to: the management of the institution, in particular in the sphere of standards compliance; workflow in the direction of balancing the expected results; culture, that is, adherence to academic excellence. It should also be noted that studying the issue of improving higher education theses researchers state that "for the field of practice, the three perspectives may serve as a reminder that in a well-functioning higher education institution, effective coordination is not only about acknowledging management and culture but also a range of local practices that are not always visible in the formalised systems".

Cardoso, Rosa and Stensaker (2016) have found that the quality of higher education in Europe is controlled both by relevant national agencies, specializing in higher education quality, and directly by institutions, providing higher education services. Moreover, scientists, in the context of developing a number of literary views on the quality problem of higher education, have determined that quality is characterized by such concepts as culture, responsibility and consistency. However, they offer to consider the quality of higher education in the face of a number of basic obstacles to quality. Herewith, it should be noted that the given research may become the basis for the development of other several effective mechanisms for ensuring the quality of higher education.

Moreover, Leiber, Stensaker and Harvey (2015) have examined basic aspects of assessing the impact of quality assurance in higher education institutions in order to improve the development of the quality of higher education and determine the knowledge effectiveness level provided by higher education institutions. In the context of the investigation, they have conducted a survey of the interested parties (students, teachers, employers, agencies specializing in quality assurance in higher education, heads of curricula, heads of higher educational institutions, government, population, in general, and the international community) concerning examining their points of view on how the modern system of ensuring the quality of higher education has changed. During the survey it has been found that the greatest impact on changing the quality assurance system of higher education was the experience gained in IQA procedures.

At the same time, Beerkens (2018) has considered an approach to quality assurance of higher education, based on a good deal of evidence identified. Consequently, the approach called the "Golden Standard" is a strict experimental evidence of the fact that it is high-quality tools that act as a means of enhancing students' learning. The proposed approach can be technically complex, quite costly and ineffective. Herewith, the given research states that the developed approach, which is based on evidence to ensure the quality of higher education, is a very attractive concept. In addition to the evidence-based approach the author also highlights the evidence-based approach, based on 
encouraging others to improve the quality of teaching in higher education institutions. Therefore, according to the researcher, the management of higher educational institutions should make efforts to critically monitor the educational process, in the context of which the material is taught to students, using a system of incentives, as well as collecting information (evidence) on the level of effectiveness of such an approach to ensuring the quality of higher education. The researcher also considers the consequences of implementing a policy approach to quality assurance in higher education, which is also based on evidence. Based on the results of using this approach, it is possible to obtain information (evidence) on the effectiveness of the policy of quality assurance in education by higher education institutions.

Jarvis (2014) has found that the dominant role in regulating higher education institutions' management processes lies in quality assurance regimes, based on neoliberal management, where political discourse is guided more by belief than evidence. At the same time, in the context of the study conducted, it was noted that currently almost half of the countries of the world have an appropriate system for ensuring the quality of higher education. For instance, direct state regulation of the quality assurance process of higher education in the member states of European Union is carried out in Denmark - Subject Assessments, in Germany - Subject Accreditation, in Spain (Catalonia) Performance-based Contracting, and the European Qualifications Framework. The scientist also states that currently the number of controlling bodies and organizations in the process of ensuring the quality of higher education is significantly increasing.

At the same time, Ardi, Hidayatno, Yuri and Zagloel (2012) have analyzed the relationship between quality measures in higher education and determined the impact of each quality measure on students' satisfaction. Regarding the detailing of quality measures in higher education, the researchers have selected such indicators, as: dedication of teachers of higher education institutions, commitment of departments of higher education institutions, preparation of courses, quality of services at the university, courtesy, customer improvement, and feedback. Scientists have found that the quality of the material's presentation, the dedication of teachers to the educational process and the suggestions in reviews to improve the quality of higher education had a positive impact on the level of students' satisfaction with higher education.

Urbanovic and Wilkins (2013) offered to apply the concept of internationalization in the context of a strategy to improve the quality of higher education in small countries with a comprehensive or universal higher education system. Such actions will make it possible to identify not only opportunities, but also the challenges facing countries in the higher education system. At the same time, the practical application of the concept of internationalization to ensure the quality of higher education, the authors conducted on the example of such a member state of European Union as Lithuania. According to the results of the study, researchers identify a number of strategies (strategy for setting clear goals; strategy for implementing a change management program; strategy for evaluating the effectiveness of internationalization of the quality of higher education; strategy of control over investment in the process of internationalization of the quality of higher education; strategy of comparing higher educational institutions with the world's best higher educational institutions; strategy of investing in staff development; staff competence development strategy, etc.) that can be implemented in small countries, such as Lithuania, in order to improve the quality of higher education.

\section{Data and Research Methodology}

Problems In the study's framework of the practical aspects of the higher education's quality in European Union's countries, the methods of theoretical analysis (to study the theoretical, methodic and methodological principles of the quality assurance system of higher education), also methods of grouping, description, comparison and synthesis (to consider and analyze the peculiarities of the formation and development of the quality assurance system of higher education in the member states of European Union and to provide recommendations to educational institutions of the member states of European Union on ensuring the proper quality of higher education and high level of educational services).

Methodological basis that characterizes the practical aspects of ensuring the quality of higher education in the countries of the European Union are reflected in a scientific paper through:

1) The dynamics of the number of students who have completed higher education (Eurostat, 2020b);

2) The structure of degree seeking applicants of higher education (Eurostat, 2020b);

3) The employment rate of graduates who have graduated from higher education (Eurostat, 2020a);

4) The World University Rankings (The Times Higher Education, 2018a, 2019a, 2020); 
5) The Europe Teaching Rankings (The Times Higher Education, 2018b, 2019b);

6) Rating of the strength of the higher education system (Quacquarelli Symonds, 2016, 2018).

\section{Results of the Research}

As part of the disclosure of the subject matter of this scientific investigation, one should consider the dynamics of changes in the number of students in European Union's countries who have completed higher education. Considering that, in 2017, compared to 2013, the overall dynamics of the number of students in EU countries, as a whole, remained almost unchanged - a slight increase by $0,65 \%$ (Table 1). During 2013-2017, the largest number of undergraduate students were present in such countries as: Germany, France, Great Britain, Spain, Italy and Poland; however, in Italy and Poland in 2017 compared to 2013, there was a decrease in the number of students who had completed higher education by $1,9 \%$ and $18,5 \%$ respectively.

Table 1. Dynamics of students enrolled in tertiary education (Eurostat, 2020b)

\begin{tabular}{|c|c|c|c|c|c|c|}
\hline No. & Countries & 2013 & 2014 & 2015 & 2016 & 2017 \\
\hline 1 & Austria & 422778 & 421225 & 425972 & 431125 & 430370 \\
\hline 2 & Belgium & 488488 & 495910 & 504745 & 508270 & 503261 \\
\hline 3 & Bulgaria & 283959 & 283294 & 278953 & 266707 & 249937 \\
\hline 4 & Great Britain & 2386199 & 2352933 & 2330334 & 2387280 & 2431886 \\
\hline 5 & Greece & 659284 & 677429 & 690868 & 709488 & 735027 \\
\hline 6 & Denmark & 291147 & 301399 & 313756 & 314822 & 312379 \\
\hline 7 & Estonia & 64806 & 59998 & 55214 & 51092 & 47794 \\
\hline 8 & Ireland & 199428 & 203912 & 214632 & 218411 & 225031 \\
\hline 9 & Spain & 1969413 & 1982162 & 1963924 & 1968702 & 2010183 \\
\hline 10 & Italy & 1872693 & 1854360 & 1826477 & 1815950 & 1837051 \\
\hline 11 & Cyprus & 31965 & 33674 & 37166 & 40347 & 45263 \\
\hline 12 & Latvia & 94474 & 89671 & 85881 & 84282 & 82914 \\
\hline 13 & Lithuania & 159695 & 148389 & 140629 & 133759 & 125863 \\
\hline 14 & Luxembourg & 6617 & 6788 & 6896 & 6954 & 7058 \\
\hline 15 & Malta & 12574 & 12610 & 13216 & 13764 & 14425 \\
\hline 16 & The Netherlands & 674752 & 702183 & 842601 & 836946 & 875455 \\
\hline 17 & Germany & 2780013 & 2912203 & 2977781 & 3043084 & 3091694 \\
\hline 18 & Poland & 1902718 & 1762666 & 1665305 & 1600208 & 1550203 \\
\hline 19 & Portugal & 360818 & 362200 & 337507 & 343117 & 346963 \\
\hline 20 & Romania & 618157 & 578706 & 541653 & 535218 & 531586 \\
\hline 21 & Slovakia & 209543 & 197854 & 184390 & 167280 & 156048 \\
\hline 22 & Slovenia & 97706 & 92769 & 85616 & 80798 & 79547 \\
\hline 23 & Hungary & 359040 & 329455 & 307729 & 295328 & 287018 \\
\hline 24 & Finland & 309009 & 306080 & 302478 & 297163 & 295528 \\
\hline 25 & France & 2338135 & 2388880 & 2424158 & 2480186 & 2532831 \\
\hline 26 & Croatia & 164623 & 166061 & 162022 & 162017 & 165197 \\
\hline 27 & The Czech Republic & 427441 & 418624 & 395529 & 371948 & 352873 \\
\hline 28 & Sweden & 436603 & 429444 & 428557 & 426188 & 426354 \\
\hline
\end{tabular}

In terms of the structure of degree seeking applicants of higher education, the largest share, which in addition to 2013, increased by $0,3 \%$ compared to 2013 , was held by applicants who had received their initial higher education. (Short-cycle tertiary education) (Figure 1). The share of applicants for a bachelor's degree of higher education 
(Bachelor's or equivalent level) is slightly lower, which in 2017, compared to 2013, decreased by 0,33\%. Significantly less number of applicants both in 2017 and in 2013 received a master's degree of higher education (Master's or equivalent level) and a doctoral degree of higher education (Doctoral or equivalent level).

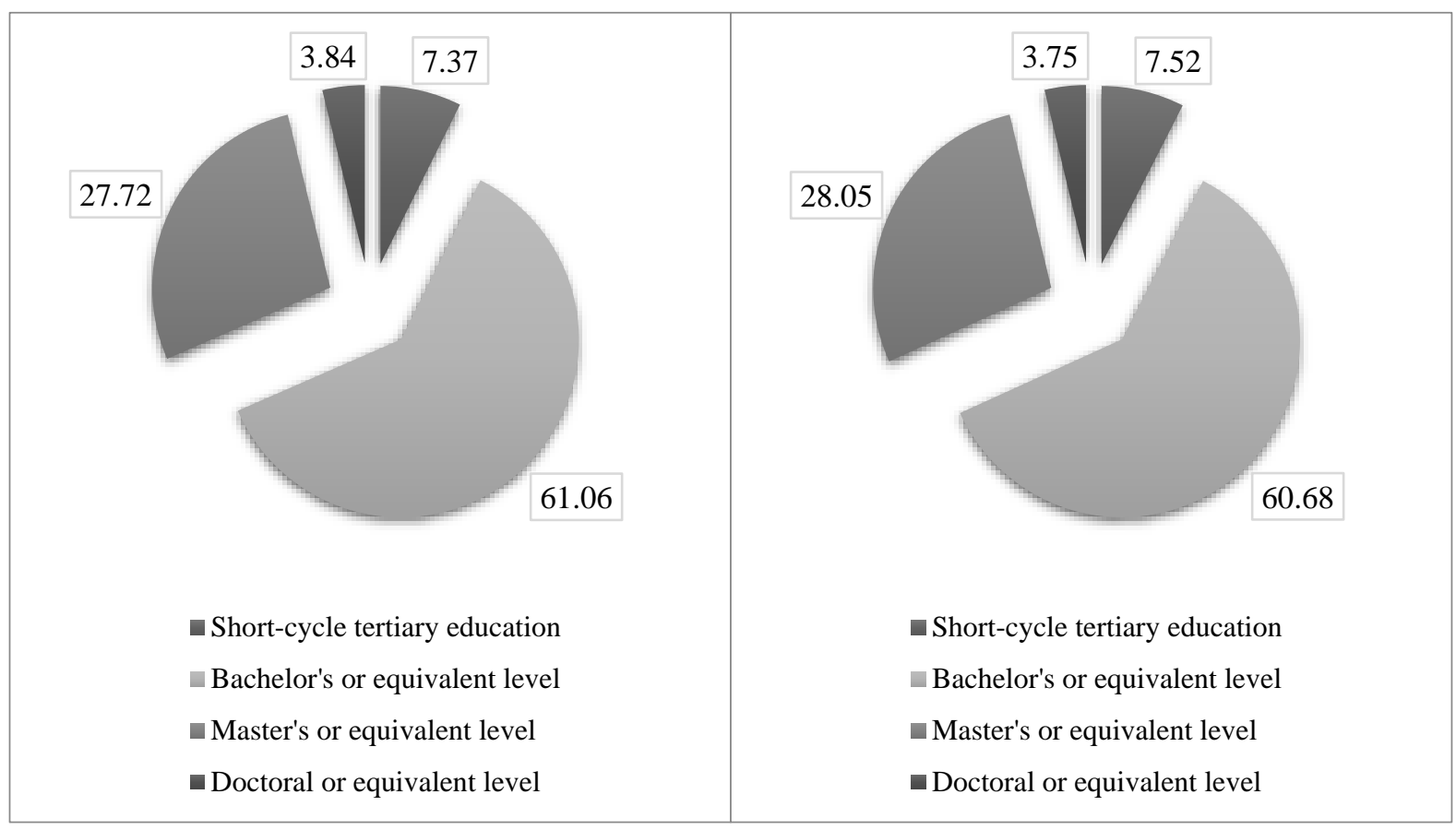

Figure1. Structure of degree seeking applicants of higher education in European Union countries in 2017 and 2013, respectively, \% (Eurostat, 2020b)

Studies show that the highest employment rate of graduates who have completed higher education in 2013 and during 2017-2018 is revealed in Malta, Germany, the Netherlands, the Czech Republic, Austria, Sweden, Luxembourg, Hungary, Great Britain and Denmark, which hold more than $85 \%$ (with the exception of the Czech Republic, Sweden, Luxembourg, Great Britain in 2013 and Hungary and Denmark in 2013 and 2017) of the total graduates of higher education institutions (Figure 2).

In order to study the practical aspects of quality assurance in higher education, the ranking of the leading universities in European Union's countries should be analyzed. Therefore, according to the Times Higher Education magazine, which annually determines the World University Rankings, the following universities are included in the top 10 most prestigious universities of European Union, namely: the University of Oxford, the University of Cambridge and Imperial College London located in Great Britain (Table 2). In addition, according to the World University Rankings, the top 20 most prestigious universities of European Union's countries are located in Great Britain, Germany, Sweden, Belgium, France and the Netherlands.

At the same time it should be noted that Times Higher Education magazine also determines the Europe Teaching Rankings. Accordingly, both in 2018 and in 2019, the University of Oxford, the University of Cambridge, UCL, the University of Warwick and the University of Bristol in Great Britain and the University of Navarra located in Spain, remain the most prestigious universities in this rating (Table 3).

In the context of studying the quality insurance problems of higher education, the strength of the higher education system of each country of European Union's countries should be analyzed. Therefore, according to the British consulting company Quacquarelli Symonds, Great Britain, Germany, France and the Netherlands have a strong higher education system among the countries of the European Union (Figure 3).

Spain, Italy, Sweden, Belgium and Finland also have a high strength in higher education, in contrast to the top 10 leading countries. 


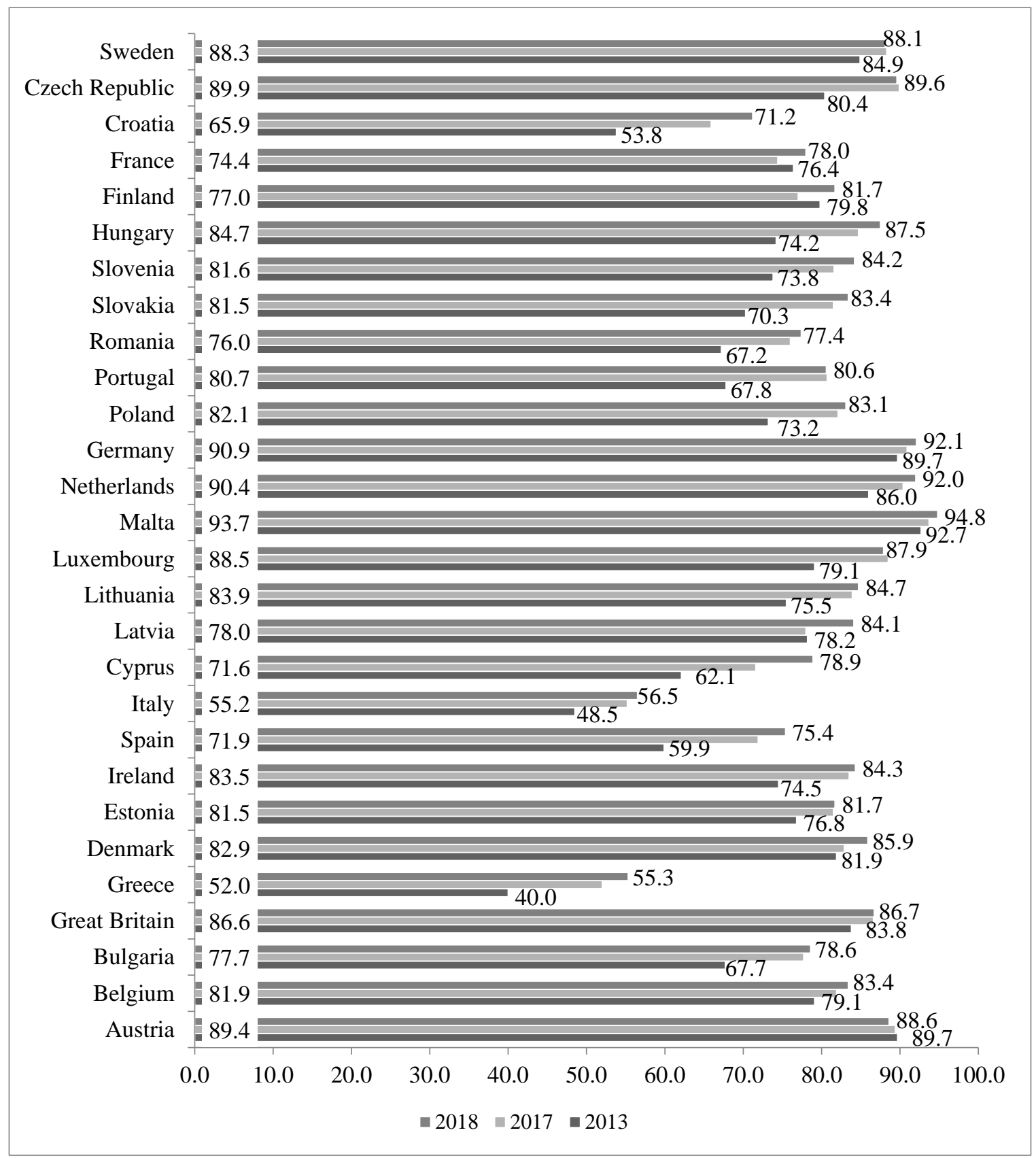

Figure 2. Employment rate of graduates of European Union's countries who have graduated from higher education institutions (Employment rates of recent graduates), \% (Eurostat, 2020a)

Table 2. Ranking of the top 20 most prestigious universities in European Union's countries according to the World University Rankings (The Times Higher Education, 2018a, 2019a, 2020)

\begin{tabular}{cccccc}
\hline No. & Universities & Location & 2018 & 2019 & 2020 \\
\hline 1 & The University of Oxford & Oxford, ENG, the United Kingdom & 1 & 1 & 1 \\
2 & The University of Cambridge & Cambridge, ENG, the United Kingdom & 2 & 2 & 3 \\
3 & Imperial College London & London, ENG, the United Kingdom & 8 & 9 & 10 \\
4 & The University College London (UCL) & London, ENG, the United Kingdom & 16 & 15 & 13 \\
5 & Ludwig-Maximilians-University & München, Germany & 34 & 32 & 32 \\
\hline
\end{tabular}


(LMU) Munich

6 King's College London

$7 \quad$ Karolinska Institute

8 Technical University of Munich

9 The University of Heidelberg

10 KU Leuven

11 PSL Research University

12 The University of Manchester

13 Wageningen University and Research

14 The University of Amsterdam

15 Delft University of Technology (TU Delft)

16 Leiden University

17 Erasmus University Rotterdam

18 The University of Groningen

19 Humboldt University Berlin

20

Utrecht University

$\begin{array}{cccc}\text { London, ENG, the United Kingdom } & 36 & 38 & 38 \\ \text { Stockholm, Sweden } & 38 & 40 & 41 \\ \text { München, Germany } & 41 & 44 & 43 \\ \text { Heidelberg, Germany } & 45 & 47 & 44 \\ \text { Leuven, Belgium } & 47 & 48 & 45 \\ \text { Paris, France } & 72 & 41 & 45 \\ \text { Manchester, ENG, the United Kingdom } & 54 & 57 & 55 \\ \text { Wageningen, the Netherlands } & 64 & 59 & 59 \\ \text { Amsterdam, the Netherlands } & 59 & 62 & 62 \\ \text { Delft, the Netherlands } & 63 & 58 & 67 \\ \text { Leiden, the Netherlands } & 67 & 68 & 67 \\ \text { Rotterdam, the Netherlands } & 72 & 70 & 69 \\ \text { Groningen, the Netherlands } & 83 & 79 & 73 \\ \text { Berlin, Germany } & 62 & 67 & 74 \\ \text { Utrecht, the Netherlands } & 68 & 74 & 75\end{array}$

Table 3. Ranking of the top 15 universities in European Union countries according to the level of teaching at universities represented by the Europe Teaching Rankings (The Times Higher Education, 2018b, 2019b)

\begin{tabular}{|c|c|c|c|c|c|}
\hline Rank & Universities & $\begin{array}{l}\text { Grade as } \\
\text { of } 2019\end{array}$ & Rank & Universities & $\begin{array}{l}\text { Gradeas } \\
\text { of } 2018\end{array}$ \\
\hline 1 & $\begin{array}{l}\text { The University of Oxford } \\
\text { (United Kingdom) }\end{array}$ & 80,9 & 1 & $\begin{array}{l}\text { The University of Oxford } \\
\text { (United Kingdom) }\end{array}$ & 83,0 \\
\hline 2 & $\begin{array}{l}\text { The University of Cambridge } \\
\text { (United Kingdom) }\end{array}$ & 80,1 & 2 & $\begin{array}{l}\text { The University of Cambridge } \\
\text { (United Kingdom) }\end{array}$ & 82,7 \\
\hline 3 & $\begin{array}{l}\text { The University of Navarra } \\
\text { (Spain) }\end{array}$ & 80,0 & 3 & Sorbonne University (France) & 81,4 \\
\hline 4 & UCL (United Kingdom) & 79,0 & 4 & $\begin{array}{l}\text { The University of Warwick } \\
\text { (United Kingdom) }\end{array}$ & 81,3 \\
\hline 5 & $\begin{array}{l}\text { The University of St Andrews } \\
\text { (United Kingdom) }\end{array}$ & 78,7 & 5 & UCL (United Kingdom) & 81,2 \\
\hline 6 & $\begin{array}{l}\text { King's College London (United } \\
\text { Kingdom) }\end{array}$ & 78,2 & 6 & $\begin{array}{l}\text { The University of Bristol } \\
\text { (United Kingdom) }\end{array}$ & 81,1 \\
\hline 7 & $\begin{array}{l}\text { Lancaster University (United } \\
\text { Kingdom) }\end{array}$ & 77,0 & 7 & $\begin{array}{l}\text { The University of Manchester } \\
\text { (United Kingdom) }\end{array}$ & 80,6 \\
\hline 8 & $\begin{array}{l}\text { The University of Warwick } \\
\text { (United Kingdom) }\end{array}$ & 76,9 & 8 & $\begin{array}{c}\text { The University of Navarra } \\
\text { (Spain) }\end{array}$ & 80,1 \\
\hline 9 & $\begin{array}{l}\text { The University of Bristol } \\
\text { (United Kingdom) }\end{array}$ & 76,7 & 9 & $\begin{array}{l}\text { Newcastle University (the } \\
\text { United Kingdom) }\end{array}$ & 79,9 \\
\hline 10 & $\begin{array}{l}\text { The University of Edinburgh } \\
\text { (United Kingdom) }\end{array}$ & 76,7 & 10 & $\begin{array}{l}\text { The University of York } \\
\text { (United Kingdom) }\end{array}$ & 79,9 \\
\hline 11 & $\begin{array}{l}\text { The University of Manchester } \\
\text { (United Kingdom) }\end{array}$ & 76,7 & 11 & $\begin{array}{l}\text { Imperial College London } \\
\text { (United Kingdom) }\end{array}$ & 79,6 \\
\hline 12 & $\begin{array}{l}\text { Autonomous University of } \\
\text { Barcelona (Spain) }\end{array}$ & 76,4 & 12 & $\begin{array}{c}\text { University of Sheffield (United } \\
\text { Kingdom) }\end{array}$ & 79,6 \\
\hline
\end{tabular}




\begin{tabular}{cccccc}
\hline 13 & $\begin{array}{c}\text { London School of Economics } \\
\text { and Political Science (United } \\
\text { Kingdom) }\end{array}$ & 76,3 & 13 & $\begin{array}{c}\text { King's College London } \\
\text { (United Kingdom) }\end{array}$ & 79,5 \\
$\quad \begin{array}{c}\text { Imperial College London } \\
\text { (United Kingdom) }\end{array}$ & 76,2 & 14 & $\begin{array}{c}\text { University of Edinburgh } \\
\text { (United Kingdom) }\end{array}$ & 79 \\
$\quad \begin{array}{c}\text { The University of Nottingham } \\
\text { (United Kingdom) }\end{array}$ & 76,2 & 15 & $\begin{array}{c}\text { University of St Andrews } \\
\text { (United Kingdom) }\end{array}$ & 78,6 \\
\hline
\end{tabular}

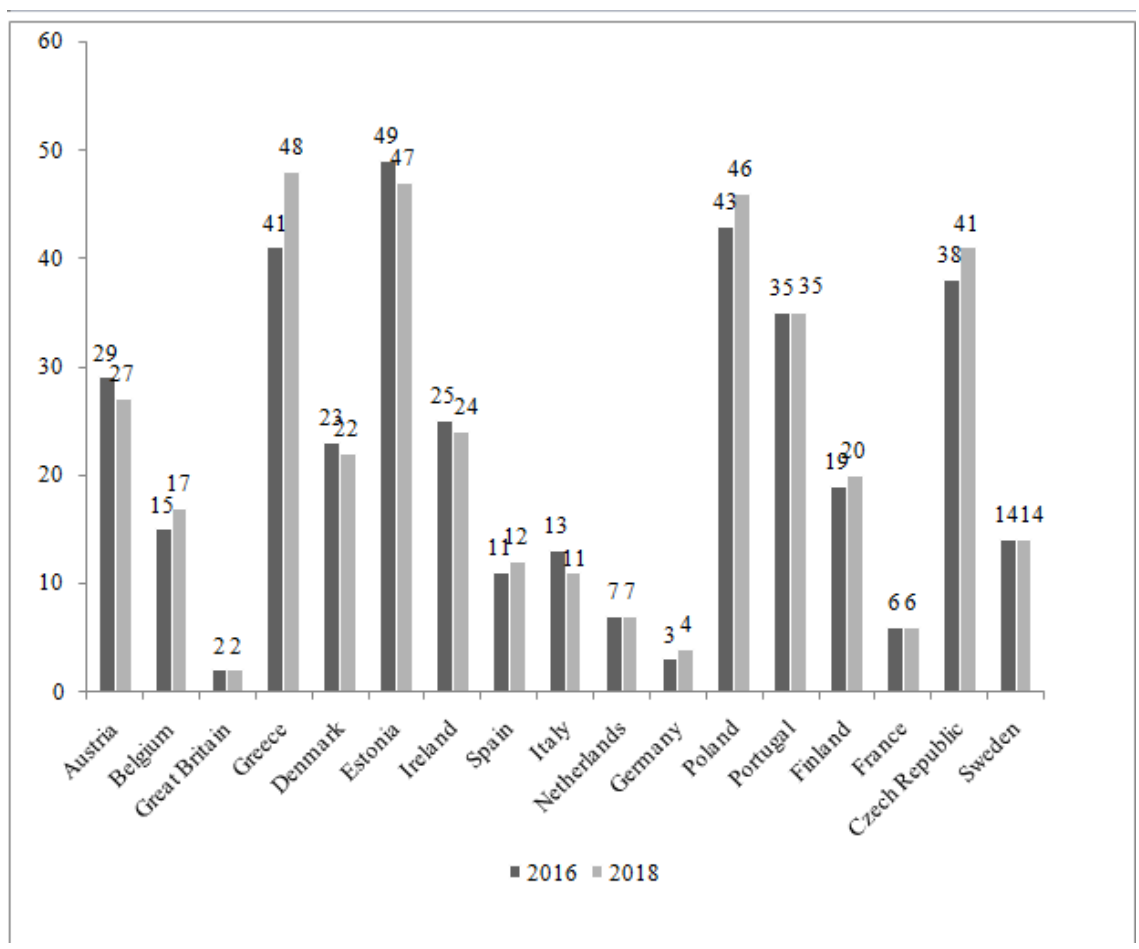

Figure 3. Strength rating of the higher education system of EU countries (Quacquarelli Symonds, 2016, 2018)

\section{Discussion}

According Based on the studies conducted, as well as accordingto the practical aspects'analysisof the quality system's functioning of higher education in the countries of European Union, it has been established that, in contrast to the generally accepted European standards, the internal quality assurance of higher education in the higher education institutions of each of the countries of the European Union is individual.

According to the results of processing the data of the World University Rankings, it has been determined that some of the most prestigious universities in the world, included in the top 10, are the universities of European Union, such, as: the University of Oxford, the University of Cambridge та Imperial College London, located in the United Kingdom. According to The Europe Teaching Rankings presented by Times Higher Education it has been determined that the most prestigious universities are the University of Oxford, the University of Cambridge, UCL, the University of Warwick, the University of Bristol in the United Kingdom and the University of Navarra, located in Spain.

Quality assurance should take into account relevant national regulations in the field of higher education and, given that higher education lies at the core of several of the sustainable development goals (SDGs) for 2030, it can also contribute to the success of this global initiative. Concerning the effective equality between women and men, SDG5 contemplates the strengthening of gender equality governance at all levels (Benito \& Verge, 2020).

In the context of ensuring the proper quality of higher education and a high level of educational services, educational institutions of the countries of European Union are recommended:

1) To review and improve the policy and directions of ensuring the quality of higher education;

2) To approve, review and monitor the results of the implementation of their own curricula, as well as to explore the basic aspects and benefits of training programs implemented by other educational institutions; 
3) To improve the quality and level of educational services, and to develop the creative potential of teachers;

4) To conduct a proper assessment of students according to approved criteria and rules;

5) To advance the educational process in accordance with the tendencies of modern innovative and scientific and technical development, etc.

National guidelines for prosthetics and orthotics programmes have previously been developed in some countries. The UK had the National Health Service and Quality Assurance Agency subject benchmark for prosthetics and orthotics. Other countries have professional association guidelines for programmes, for example, Australia. Ramstrand and Ramstrand have recently published competency standards for graduates of prosthetics and orthotics in Sweden. Aminian and O'Toole compared international curricula and identified both common and distinct areas. The International Society of Prosthetics and Orthotics has guidelines for the education of prosthetists and orthotists, which were being updated during the initial stages of this project (Hill et al., 2020).

Learning outcomes are now common internationally across higher education programmes and a central part of the Bologna Process and the European Qualifications Framework. The intention is to focus higher education on output rather than input. As well as part of the learning, teaching and assessment process, learning outcomes are also linked to governance and management. Learning outcomes are expressed, from the perspective of the student, as what a student is expected to be able to do at the end of the learning activity. They should include a verb that enables observable and assessable outcomes, with Bloom's taxonomy often being used.

\section{Conclusions}

Thus, as part of the disclosure of the subject matter of a scientific paper, it has been established that developing countries should be guided by the standards and recommendations put forward by leading countries in the field of ensuring the quality of higher education in order to improve the quality of educational services. The study has analyzed the practical aspects of quality assurance in higher education in European Union's countries through such indicators as: the dynamics of the number of students who have completed higher education; the structure of degree seeking applicants of higher education; the employment rate of graduates who have graduated from higher education (Employment rates of recent graduates); the World University Rankings; the Europe Teaching Rankings; rating of the strength of the higher education system (the QS Higher Education System Strength Rankings). Herewith, studies of the dynamics of the number of students, enrolled at higher educational institutions, showed that during 2013-2017 the largest number of students was present in such European Union member states as Germany, France, Great Britain, Spain, Italy and Poland. It has been revealed that in the structure of applicants for higher education, the largest share, which also increased in 2017, compared to 2013, by $0,3 \%$, was occupied by applicants who received primary higher education. It has been determined that the highest employment rates of graduates who graduated from higher educational institutions in 2013 and during 2017-2018 were present in Malta, Germany, the Netherlands, the Czech Republic, Austria, Sweden, Luxembourg, Hungary, the United Kingdom and Denmark, which occupy more than $85 \%$ (excluding the Czech Republic, Sweden, Luxembourg, the United Kingdom in 2013 and Hungary and Denmark in 2013 and 2017) of the total number of graduates of higher educational institutions. According to the results of the research conducted, proposals for ensuring the quality of higher education and a high level of provision of educational services have been presented to the educational institutions of the countries of European Union.

\section{References}

Adams, S., Cummins, M., Davis, A., Freeman, A., Hall, C., \& Ananthanarayanan, V. (2017). NMC Horizon Report: 2017 Higher Education Edition. Austin, TX: The New Media Consortium.

Ardi, R., Hidayatno, A., Yuri M., \& Zagloel, T. (2012). Investigating relationships among quality dimensions in higher education. Quality, 20(4), 408-428. https://doi.org/10.1108/09684881211264028

Arrosagaray, M., González-Peiteado, M., Pino-Juste, M., \& Rodríguez-López, B. (2019). A comparative study of Spanish adult students' attitudes to ICT in classroom, blended and distance language learning modes. Computers \& Education, 134, 31-40. https://doi.org/10.1016/j.compedu.2019.01.016

Beerkens, M. (2018). Evidence-based policy and higher education quality assurance: progress, pitfalls and promise. European Journal of Higher Education, 8(3), 272-287. https://doi.org/10.1080/21568235.2018.1475248

Benito, E., \& Verge, T. (2020). Gendering higher education quality assurance: a matter of (e)quality. Quality in Higher Education, 26(1), 1-16. https://doi.org/10.1080/13538322.2020.1769268 
Cardoso, S., Rosa, M. J., \& Stensaker, B. (2016). Why is quality in higher education not achieved? The view of academics. Assessment \& Evaluation in Higher Education, 41(6), 950-965. https://doi.org/10.1080/02602938.2015.1052775

Elken, M., \& Stensaker, B. (2018). Conceptualising "quality work" in higher education. Quality in Higher Education, 24(3), 189-202. https://doi.org/10.1080/13538322.2018.1554782

Eurostat. (2020a). Employment rates of recent graduates. Retrieved from https://ec.europa.eu/eurostat/databrowser/view/tps00053/default/table?lang=en

Eurostat. (2020b). Students enrolled in tertiary education by education level, programme orientation, sex and age. Retrieved from https://appsso.eurostat.ec.europa.eu/nui/show.do?dataset=educ_uoe_enrt02\&lang=en

Filippakou, O. (2011). The idea of quality in higher education: a conceptual approach. Discourse: Studies in the Cultural Politics of Education, 32(1), 15-28. https://doi.org/10.1080/01596306.2011.537068.

Hill, S., Rusaw, D. F., Goihl, T., Hjerman, A. K., Schwannborg, L. R., \& Bauge, K. (2020). Development of national curriculum guidelines using a modified RAND/UCLA appropriateness method. Quality in Higher Education, 26(2), 1-14. https://doi.org/0.1080/13538322.2020.1769266

Jain, M., \& Tyagi, R. (2017). Education standard can be improved by integrating. ICT in Education. International Education \& Research Journal, 3(10), 77-80.

Jarvis, D. S. L. (2014). Regulating higher education: Quality assurance and neo-liberal managerialism in higher education - A critical introduction. Policy and Society, 33(3), 155-166. https://doi.org/10.1016/j.polsoc.2014.09.005

Keane, T., Keane, W. F., \& Blicblau, A. S. (2016). Beyond traditional literacy: Learning and transformative practices using ICT. Education and Information Technologies, 21(4), 769-781. https://doi.org.ezproxy.uned.es/10.1007/s10639-014-9353-5

Leiber, T., Stensaker, B., \& Harvey, L. (2015). Impact evaluation of quality assurance in higher education: methodology and causal designs. Quality in Higher Education, 21(3), 288-311. https://doi.org/10.1080/13538322.2015.1111007

Quacquarelli Symonds. (2016). Higher education System Strength Rankings 2016. Retrieved from https://www.topuniversities.com/system-strength-rankings/2016

Quacquarelli Symonds. (2018). Higher education System Strength Rankings 2018. Retrieved from https://www.topuniversities.com/system-strength-rankings/2018

Seyfried, M., \& Pohlenz, P. (2018). Assessing quality assurance in higher education: quality managers' perceptions of effectiveness. European Journal of Higher Education, 8(3), 258-271. https://doi.org/10.1080/21568235.2018.1474777

Stewart, C., \& Wolodko, B. (2016). University Educator Mindsets: How Might Adult Constructive Developmental Theory Support Design of Adaptive Learning? Mind, Brain, and Education, 10, 247-255. https://doi.org/10.1111/mbe.12126

The Times Higher Education. (2018a). World University Rankings 2018. Retrieved from https://www.topuniversities.com/university-rankings/world-university-rankings/2018

The Times Higher Education. (2018b). Europe Teaching Rankings 2018. Retrieved from https://www.timeshighereducation.com/rankings/europe-teaching/2018\#!/page/0/length/25/sort_by/rank/sort_or der/asc/cols/undefined

The Times Higher Education. (2019a). World University Rankings 2019. Retrieved from https://www.timeshighereducation.com/world-university-rankings/2019/world-ranking\#!/page/0/length/25/sort_ by/rank/sort_order/asc/cols/stats

The Times Higher Education. (2019b). Europe Teaching Rankings 2019. Retrieved from https://www.timeshighereducation.com/rankings/europe-teaching/2019\#!/page/0/length/25/sort_by/rank/sort_or der/asc/cols/undefined

The Times Higher Education. (2020). World University Rankings 2020. Retrieved from https://www.timeshighereducation.com/world-university-rankings/2020/world-ranking 
Urbanovic, J., \& Wilkins, S. (2013). Internationalisation as a strategy to improve the quality of higher education in small states: Stakeholder perspectives in Lithuania. Higher Education Policy, 26(3), 373-396. https://doi.org/10.1057/hep.2013.6 